Author Version: J. Environ. Manage., vol.148; 2015; 124-133.

\title{
Implications of Sea Level Rise Scenarios on Land use /Land cover classes of the Coastal Zones of Cochin, India
}

\author{
R.Mani Murali ${ }^{1}$, P.K.Dinesh Kumar ${ }^{2}$ \\ ${ }^{1}$ CSIR-National Institute of Oceanography, Dona Paula, Goa-403004, India \\ Email:mmurai@nio.org \\ ${ }^{2}$ Regional Centre, CSIR-National Institute of Oceanography, Kochi, India \\ Email: pkdineshkumar@yahoo.com
}

\begin{abstract}
Physical responses of the coastal zones in the vicinity of Cochin, India due to sea level rise are investigated based on analysis of inundation scenarios. Quantification of potential habitat loss was made by merging the Landuse /Landcover (LU/LC) prepared from the satellite imagery with the digital elevation model. Scenarios were generated for two different rates of sea level rise and responses of changes occurred were made to ascertain the vulnerability and loss in extent. LU/LC classes over laid on $1 \mathrm{~m}$ and $2 \mathrm{~m}$ elevation showed that it was mostly covered by vegetation areas followed by water and urban zones. For the sea level rise scenarios of $1 \mathrm{~m}$ and $2 \mathrm{~m}$, the total inundation zones were estimated to be $169.11 \mathrm{~km}^{2}$ and $598.83 \mathrm{~km}^{2}$ respectively using Geographic Information System (GIS). The losses of urban areas were estimated at $43 \mathrm{~km}^{2}$ and $187 \mathrm{~km}^{2}$ for the 1 $\mathrm{m}$ and $2 \mathrm{~m}$ sea level rise respectively which is alarming information for the most densely populated state of India. Quantitative comparison of other LU/LC classes showed significant changes under each of the inundation scenarios. The results obtained conclusively point that sea level rise scenarios will bring profound effects on the land use and land cover classes as well as on coastal landforms in the study region. Coastal inundation would leave ocean front and inland properties vulnerable. Increase in these water levels would alter the coastal drainage gradients. Reduction in these gradients would increase flooding attributable to rainstorms which could promote saltwater intrusion into coastal aquifers and force water tables to rise. Changes in the coastal land forms associated with inundation generate concern in the background that the coastal region may continue to remain vulnerable in the coming decades due to population growth and development pressures.
\end{abstract}

Key words: Land Use, Land Cover, Sea level rise, Inundation, Vulnerability, Cochin, India 


\section{Introduction:}

Global sea level rise (SLR) ranging from $0.5 \mathrm{~m}$ to $2 \mathrm{~m}$ has been predicted over the next century and it would disrupt the physical processes, economic activities and social systems in the coastal zones (Gommes et al., 1997; NOAA Report, 1999; Solomon et al., 2007). Besides the destruction through increased rates of erosion, sea level rise situations increase the risk of inundation (Nicholls et al., 1999). Among the different impacts of climate change, sea level rise raise much concern mainly due to the direct physical impact of inundation and potential habitat loss. A comparative analysis on the impact of permanent inundation due to sea level rise on 84 countries of the world revealed that hundreds of millions of people in the developing nations are likely to be displaced (Dasgupta et al., 2007). Inundation poses substantial risks to coastal communities which are projected to increase with the accelerated sea level rise along vulnerable shorelines (Solomon et al., 2007). As a consequence of various factors, $2.3 \mathrm{~m} \mathrm{C}-1$ sea level rise is expected in the next 2000 years (Levermann et al., 2013). GIS techniques were used to delineate the inundation areas in Mekong Delta region, Vietnam under SLR scenarios of $20 \mathrm{~cm}$ and $45 \mathrm{~cm}$. The results were that the water levels will be shifted to $25 \mathrm{~km}$ and $50 \mathrm{~km}$ towards the sea (Wassmann R et al., 2004). Reece et al 2013 characterized the vulnerability to major threats to biodiversity of Florida region using the projections of SLR by the year 2100 and human land use pattern. If the global sea level rises in the manner predicted, there will be extensive submergence of low-lying coastal areas. The highest tide will reach above their present limits and the low tide line will move landward. These will result into the existing intertidal area to become permanently submerged. Variations resulting will be site specific and depending on coastal configuration, near shore sea floor morphology and associated erosion and deposition characteristics. It is essential to quantify the risks associated with SLR to provide decision makers with relevant guidance regarding the existing and future coastal infrastructure development. Thus, problem of assessing the impacts of sea level rise scenarios to existing coastlines is appropriate and extremely challenging. The increased inundation may lead to substantial socio-economic losses, such as the loss of coastal structures, damage to buildings and settlements, dislocation of the population and the loss of agriculture and industrial production. The impacts in total affect infrastructure, ecology, public health and services. There has been a growing awareness of understanding in the extent of flooding due to sea level rise along the coastal zones (Robert and Devoy, 2008; Marfai and Lorenz, 2008; Kathrin and Cathal ,2011; Kwasi et al., 2011; Marfai and Hizbaron Dyah R., 2011; Kathleen et al., 2013; Simav et al., 2013). Spatial analysis using LIDAR technology was tried to SLR inundation areas (Cooper H., et al., 2013).

Because of the complexity of the coastal systems and their regional variations, a great deal of site specific research is required to realistically assess and predict the extent of geomorphic and ecological changes in the coastal zones that will occur with sea level rise (Nicholls and Mimura, 1998; Rahmstorf, 2012). Sea Level Rise and the complexities of land use coastal communities were assessed in southeast Australia and adaptation planning guidelines were provided (Lin B., et al, 2013). Inundation maps prove to be useful for visualizing the potential impact and extent of sea level rise inundation. There are various uses for these maps which include: assessing and planning land use and zoning laws to protect community resources; developing strategies for natural disaster management plans; preparing future plans for infrastructure and planning for coastal community resilience by determining hazards and vulnerability. 
The Indian coastline, about $7500 \mathrm{~km}$ long, supports large number cities which are subjected to severe ecological pressures. Regional average sea level rise is $1.29 \mathrm{~mm} / \mathrm{y}$ for this region (Unnikrishnan and Shankar. 2007). Climate change assessment and its impacts were studied on different aspects for several of parts of India (INCCA report 2010, NIO report 2010, Mani Murali, 2013). Shoreline changes and vulnerability of Indian coast (Mani Murali et al., 2009, 2010, 2013) and run up, inundation limits (Jaya Kumar et al., 2005) were studied along the parts of east coast of India for anthropogenic and Tsunami studies respectively. The likelihood of increased frequency of tropical cyclones will trigger the surges and sea level is likely to increase during the surge time (Unnikrishnan, et al., 2006). Many cities have developed along the coasts and they multiply out of control with resources used with thoughtless abandon. Substantial changes are taking place in the landscape of these systems as a result of the dramatic and rapid urbanization. As elsewhere, Cochin, a city along the West coast of India too has expanded rapidly and heavily stressed from environmental perspectives. Cochin has good reason to be concerned as global climate change issues further pose severe problems to its coastal zones. The coastal zones of Cochin, southwest coast of India are targeted here to address the anticipatory issues resulting due to inundation. The study aims to quantify the habitat loss and the changes in the land use and land cover classes in the coastal zones derived from satellite imagery for different SLR scenarios.

\section{Study area:}

Cochin (Kochi), ( $\left.9^{\circ} 58^{\prime} \mathrm{N}, 76^{\circ} 14^{\prime} \mathrm{E}\right)$ is a charming coastal city situated in the state of Kerala on the southwest coast of India (Figure 1). Hailed as the 'Queen of Arabian Sea, it is the biggest city along the west coast of India after Bombay (Mumbai). It consists of a number of low-lying islands, peninsulas with parts of the mainland linked by water bodies, rivers, canals and a major international harbor. At the northern end of the Cochin coastline, the river Periyar opens to the Arabian Sea through Cochin Backwaters. Even though the backwaters are a hydraulic continuum spreading over the entire state, the backwater system located between $09^{\circ} 30^{\prime}-10^{\circ} 10^{\prime} \mathrm{N}, 76^{\circ} 15^{\prime}-76^{\circ} 25^{\prime} \mathrm{E}$ is generally known as Cochin backwaters. Constant mixing with the seawater through tidal exchange gives the backwaters the characteristics of a typical estuary. The estuary depicts an interesting physiography dominated by several inner estuary islands (Figure 1). The port facilities are located at the mouth of the Cochin estuary. A highlight of the port is that it provides an absolutely placid water spread which retains its calmness even during the rough weather as the vast and extremely tranquil harbor basin is protected by the peninsular headlands on each side. The region is characterized by a high population density. Coastal population in the adjacent zones has grown several folds over the recent decades, with several sub regions in the study area displaying growth rates often exceeding $100 \%$. The urban agglomeration population of this region has grown from 8.24 to 21.17 lakhs from the year 1981 to 2011. The annual increase of $3 \%$ is also estimated (http://www.indiaonlinepages.com/population/kochi-population.html). The Population density of 859 per sq.km in this region adds the vulnerability as more number of people will be affected in case of any eventuality. The elevation of this region is almost flat. The average elevation of the western city is about $1.5 \mathrm{~m}$ and eastern side is $7.5 \mathrm{~m}$ from MSL. The area is warm and humid, with two monsoon periods occur annually. Total precipitation is about $3000 \mathrm{~mm}$ annually about two-thirds of that comes during Southwest monsoon period (June-August). The water movements in the region are closely associated with the tidal patterns. The tides experienced in the region are mixed semi-diurnal 
type with unequal tidal amplitudes occurring each day. The tidal ranges vary considerably through neap and springs, with the higher water springs and lower water springs being $1.05 \mathrm{~m}$ and $0.20 \mathrm{~m}$ respectively (Anonymous, 2013). Littoral processes of the region have been extensively studied (Shenoi, 1984; Prasanna Kumar, 1985; Sajeev, 1993; Dinesh Kumar, 2000). Monthly mean sea level for 50 years were studied at Cochin and variations during the different season of the year were reported (Dineshkumar.P.K., 2001).

The coastal landforms are made up of sand bars and barriers, sandy flats, mud flats and bars. The near shore zones of Cochin are relatively shallow- reaching a water depth of less than $5 \mathrm{~m}$ at a distance of about $2 \mathrm{~km}$. The coastal plain is thus mostly low and slopes gently seaward at several places which imply that, a slight increase in sea level would result in a significant horizontal displacement (Dinesh Kumar, 1995). From the results obtained on the coastal sedimentary environments, it was found that climate-induced sea level rise will bring profound effects in the region (Dinesh Kumar, 2006).

\section{Data and Methodology:}

Inundation mapping and analysis of flooding impacts demands data on the land surface elevations, land use and land cover. Quantification of potential habitat loss can be estimated by merging the land use /land cover with the digital elevation model (Xingong et al., 2009). Linear Imaging Self Scanner (LISS) III is one of the best sensors of Indian Remote Sensing (IRS) satellites with $23.5 \mathrm{~m}$ spatial resolution. Shuttle Radar Topographic Mission (SRTM) provides topographic data for the whole globe with $90 \mathrm{~mm}$ resolution. IRS P6 LISS III image of 2007 has been used for deriving the different land use/ land cover classes and SRTM digital elevation model is used to extract the different elevation areas. (Divyalaxmi, 2009). The toposheets (58B4, 58B8, 58C1, 58C5, 58C6) of Survey of India (SOI) pertaining to the study area were geo-referenced and mosaiced using image processing software ERDAS 9.1. The ground control points (GCP's) for geo-coding the satellite imagery were found out with the help of geo-referenced toposheets and the GCP's were uniformly distributed across the study area. The overall accuracy expressed as the Root Mean Square Method (RMSE) for geo-referenced images was less than 0.8. After geo-referencing, nearest neighbor interpolation method was employed for rectifying and re-sampling the images into Geographic coordinate system and then re-projected to UTM (Universal Transverse of Mercator) zone 43 North projection systems. Supervised classification was used to generate the land use and land cover map of the region. The LU/LC classes present in the study region are water body, vegetation, urban land, sandy area/barren land. SRTM digital elevation model is one of the freely available DEM for the whole globe. A high resolution DEM with resolution of $90 \mathrm{~m}$ was prepared for the study area. LU/LC classes were overlaid on $1 \mathrm{~m}$ elevation of the DEM and the classes falling within these regions were extracted. This region is mostly covered by vegetation followed by water and urban areas. All these classes are important and crucial on social aspects. Different land use and land cover classes within the area of inundation due to sea level rise and different water level rise scenarios were demarcated. 


\section{Results and Discussion:}

Land use/land cover of the study region consists of water body, vegetation, urban land and sandy/barren land (Figure 2). The activities of agriculture, fishing, port activities, industries, infrastructure activities and tourism are also common. As these activities are growing year by year, urban areas are also increasing linearly to the developmental activities. The agriculture practices consist of cultivation of Paddy, Coconut, Pepper, Rubber and crops of different food items, etc. Estimates of potential habitat loss were achieved by merging the land use/land cover with the digital elevation model (DEM). IRS P6 LISS III image of year 2007 and DEM was used for deriving the different land use/land cover classes and DEM of the study region (Figure 3 and Figure 4). These classes were overlaid on $1 \mathrm{~m}$ elevation of the DEM and the classes falling on these regions were extracted. Comparative analysis showed that vegetation area was mostly covered under this scenario followed by water and urban zones (Figure 5). Very little area of sand features were found within the $1 \mathrm{~m}$ elevated level. If there is $1 \mathrm{~m}$ sea level rise in the region, the total probable extent of inundation is estimated to be $169.11 \mathrm{~km}^{2}$ (Table1). The inundation scenarios of $2 \mathrm{~m}$ rise in sea level is depicted in the figure 6. Results of extraction of classes over laid on this elevation showed that it is mostly covered by vegetation, urban and water zones (Table 2). The total probable extent of inundation is estimated to $598.82 \mathrm{~km}^{2}$. Land use/land cover area for each of the sea level rise scenarios of the $1 \mathrm{~m}$ and $2 \mathrm{~m}$ and the total inundation zone was found to be $169.11 \mathrm{~km}^{2}$ and 598.83 $\mathrm{km}^{2}$ (Table 3).It is inferred that in both of the sea level rise scenarios $(1 \mathrm{~m}$ and $2 \mathrm{~m}$ ), areas of vegetation was found to be more inundated. Cochin City comprises of urban areas which is highly populated. The loss of urban areas (Table 3) of $43 \mathrm{~km}^{2}$ and $187 \mathrm{~km}^{2}$ for $1 \mathrm{~m}$ and $2 \mathrm{~m}$ sea level rise respectively should be considered as alarming. Broad range of population and land use will suffer from this kind of coastal inundation due to sea level rise. The physiographic characteristics of the city may be the main factor for the pattern observed. Flooding would increase along the coast for several reasons and would destroy ocean front properties and leave inland properties vulnerable to storm waves; and higher water levels would reduce coastal drainage gradients. Reductions in these gradients would increase flooding attributable to rain storms which could result into the salt water intrusion into coastal aquifers and force water tables to rise and in some areas to emerge at the surface. The expected inundation would physically and economically affect the coastal zone.

Estimates of episodic and permanent land inundation in the study region were made based on prevailing conditions and sea level rise scenarios (Dinesh Kumar, 2006). However, the study was confined to the stretch of shoreline of coastal sedimentary environment, which forms part of two barrier islands with Cochin harbor mouth sandwiched in between. This method is very effective as it provides visual and quantitative estimates of inundation of all geographical zones in the study region. Results of the analysis in turn provided integrated profile of the inundations that will occur for different sea level rise scenarios. Physical processes in these zones are complex and are the net result of several factors. In the study region, influx of sediments is highly variable with season and the sediment circulation in the near shore zones in the vicinity of the estuarine mouth also varies with seasons. In response to these, mouth configuration undergoes rapid changes. The integration of these results makes the present study more comprehensive. 
The region is being inflicted with major geomorphic changes at several segments and reduction in extent. The geomorphic units are sandy plains, water bodies, tidal flats, old and recent alluvium plains (Chattopadhyay .S. 2010). Due to this SLR, the size and shape of the tidal flats, water bodies would change. The coastal plains would be permanently inundated and the loss of land is envisaged. The sediment flux would be severely altered as the bathymetry of the water bodies will change and based on that the tidal fluctuations may be modified. The sedimentation pattern also would change and seasonal changes in the beach profiles are expected to change drastically. The beach profile above water mark would shift towards the landward side and the total volume of the sediment changes will vary. The proposed structures such as sea walls, piers will change the coastal processes and will lead to more geomorphic changes along this region. The monetary losses involved will be significant as the amount of property inundated and the number of zones subject to temporary flooding increases. Raised water levels and associated impacts necessitate the designing of safe, stable and functional coastal protection structures. As sea level rises, land and structure elevations that are currently not affected by water levels will begin to be inundated and the increased flooding will result directly from the increase in high tide levels as the sea level rises. Thus, if the study region is to remain in its present form, extensive coastal engineering projects have to be implemented along with the up gradation of the existing structures. Detailed information is required to precisely assess the full range of risks and further studies are to be undertaken to investigate the physical impacts of sea level rise, such as salt water intrusion. The ground water of the study region is already facing the threat brackish quality along the tidal inlets and pollution load from anthropogenic activities (Laluraj, et al, 2005, Priju C.P., et al, 2012). The aquifers are hard rock and sedimentary type in this region. Most of these aquifers are along the coastal tract and belong to sedimentary formation. This aquifer is composed of fine to medium grained sand. The TDS is around $1379 \mathrm{mg} / \mathrm{l}$. The names of the aquifers are Vaikom and Warkali beds. The dug wells are from $2.14 \mathrm{~m}$ to $13 \mathrm{~m}$ in depth in this region. After monsoon, the water level is very shallow and less than $2 \mathrm{~m}$ below ground level throughout along the coastal belt. Water level is mostly controlled by rainwater recharge. The groundwater is mainly used for domestic, industrial and irrigation purpose. In recent times, the withdrawal of groundwater has increased and they are reaching critical and overexploited stages. Under this projected SLR scenarios, the quality of the groundwater from shallow aquifers will certainly become dreadful.

From the results obtained, it was inferred that the signatures of the inundation were found to be strong (Figure 7). Estimates of the inundation zones revealed the extended modification of the coastal zone. The analyzed data records present only the differences in area extent. No attempt could be made to compute more important aspects such as volume which has linear links to the geometry of respective subzones. Inundation also leads to geomorphic differences in the coastal zones and adjacent water bodies which lead to modify the flows. Flooding would leave ocean front and inland properties vulnerable. Higher water levels would reduce coastal drainage gradients. Reduction in these gradients would increase flooding attributable to rainstorms, could promote saltwater intrusion into coastal aquifers and force water tables to rise. Closely gridded data is required to assess the changes at different segments and the resultant reduction in volume. The present study may pave the way for detailed investigations for future. Synchronous environmental data would be useful in understanding the carrying capacity and problems and potentialities of fisheries, tourism and navigation. 


\section{Adaptive management solutions:}

Assessments of climate change impacts using the scientific data generate new knowledge. The process of adaptation includes the latest technologies as well as the traditional knowledge. Cochin is one of the most populated and fast growing cities of India and millions of dollars are invested for the infrastructural projects such as Metro rail, setting up of industries, etc. Certainly, this city will become urban conglomerate in near future. The overall probable inundation zones, its land use, land cover, the expansion plans of future and the assessment of current situation will help to devise the adaptive management. Preventive planning will reduce lot of hassles in the future. As the Earth is gearing up for adjusting with the climate change and linked up scenarios, it's worth to plan from the ground level involving government, NGO's, Public and industries. Adaptation to sea level rise situations should go with the improved versions of integrated coastal zone management projects. Mostly, agricultural lands, urban areas and vegetation zones are affected in this region. Alternate or modified agricultural practices, security for the fresh water, managing the urban and industrial areas should be initiated from this second itself.

\section{Conclusion:}

Understanding the impacts of inundation has gained increasing importance in the age of climate change and associated sea level rise. In the discussion above, we examined the projected inundation of the coastal zones of Cochin, India. As explained, anticipated SLR will affect the coastal zones of Cochin through permanent inundation of low lying areas. The results conclusively showed that the inundation level reaches much inside for $2 \mathrm{~m}$ rise in sea level. The vegetation and life in the coastal environment are expected to be affected with harmful effects for the population in the region. However, it should be considered that this magnitude of inundation comprises both the permanent and temporary components, which approximately correspond to the maximum flood level and does not reflect the duration of flooding. With the projected inundation of this magnitude (2 m SLR), the coastal zone would be at risk of flooding, where several near shore settlements will be impacted severely. Damages to this coastal city cannot be observed in isolation as it is linked with other regions through economic and cultural ties. Changes will affect the hinterlands too and chain reactions may follow. Urban planning will be confronted with a number of anticipatory issues including adaptation strategies. The present study conclusively proves the usefulness of digital elevation analysis to quantify scenarios of projected inundation and the impact on land use/land cover classes in the coastal zone. The maps produced using this technique serve as a broad indicator to raise the awareness among the people of the region and to formulate effective coastal management strategies.

\section{Acknowledgement:}

Authors thank Director, CSIR-National Institute of Oceanography (CSIR-NIO), Goa, for providing facilities and support. This is CSIR-NIO contribution No xxxx. 


\section{REFERENCES}

Anonymous, 2013., The Indian Tide Tables - Part I. Office of the geodetic and research branch, Surveyor General of India, Dehradun,238 p

Chattopadhyay, S., 2010. Geomorphology for Integrated Coastal Zone Management: A theoretical approach with examples from Kerala, India. Indian Journal of Geo-Marine Sciences 39(4), 623-630

Cooper, M.H., Fletcher, H.C., Chen, Q., Barbee, M.M., 2013. Sea-level rise vulnerability mapping for adaptation decisions using LiDAR DEMs. Progress in Physical Geography, DOI: 10.1177/0309133313496835

Dasgupta, S., Laplante, B., Meisner, C., Wheeler, D. and Yan, J., 2007. The impact of sea level rise on developing countries: A comparative analysis. World Bank Policy Research Working Paper, 4136. http://econ.worldbank.org

Dinesh Kumar, P.K. 1995. The impact of selected sea level rise scenarios in the vicinity of Cochin harbor, India. Proceedings, International Conference Coastal and Port Engineering in Developing Countries, Rio de Janerio, Brazil, 1865-1871.

Dinesh Kumar, P.K., 2000. Studies on the impact of selected sea level rise scenarios on the coast and coastal structures around Cochin, Ph.D Thesis, Mangalore University, India.125 p.

Dinesh Kumar, P.K., 2001. Monthly Mean Sea Level Variations at Cochin, Southwest Coast of India. International Journal of Ecology and Environmental Sciences 27. 209-214.

Dinesh Kumar, P.K., 2006. Potential vulnerability implications of sea level rise for the coastal zones of Cochin, southwest coast of India. Environmental Monitoring and Assessment, 123, 333-344.

Divyalaxmi, K.R., 2009. Coastal inundation mapping of Cochin area. M.Sc. Dissertation, Mangalore University, Mangalore, India, 53p.

Gommes, R., Duer ny J., Nachtergaele, F., Brinkman, R., 1997. Potential impacts of sea level rise on populations and agriculture. FAO, Rome, 175p.

IPCC, 2007, Climate Change 2007: The Physical Science Basis. Contribution of Working Group I to the Fourth Assessment Report of the Intergovernmental Panel on Climate Change [Solomon S, D Qin, M Manning, Z Chen, M Marquis, K B Averyt, M Tignor and H L Miller (eds.)]. Cambridge University Press, Cambridge, United Kingdom and New York, NY, USA, 996 pp.

INCCA report 2, 2010, Climate change and India: A 4X4 assessment, pp. 45-53. Jayakumar S, Ilangovan D et al., (2005), Run-up and inundation limits along southeast coast of India during the 26 December 2004 Indian Ocean tsunami, Current Science 88(11), 1741-1743

Kathleen L McInnes, Ian Macdam, Graeme Hubbert., Julian O’Grady., 2013. A assessment of current and future vulnerability to coastal inundation dueto sea level extremes in Victoria, southeast Australia. International Journal of Climatology, Vol.33, 1, 33-37. 
Kwasi, A.A., Lloyd, L, Barnabas, A., and Patrick, K.W., 2011. Impacts of coastal inundation due to climate change in a cluster of urban coastal communities in Ghana, west

Africa. Remote Sensing, 3(9), 20292050 .

Laluraj,C.M., Gopinath,G., Dineshkumar, P.K., 2005. Groundwater chemistry of shallow aquifers $\quad$ in the coastal zones of Cochin,India. Applied Ecology and Environmental $\quad$ Research 3(1), 133- 139

Levermann, A., Clark, U.P., Marzeion, B., Milne, G.A., Pollard, D., Radic, V., Robinson, A., 2013. The multimillennial sea-level commitment of global warming. PNAS, 110(34), 13745-13750

Lin, B.B., Khoo, B.Y., Inman, M., Wang, H.C., Tapsuwan, S., Wang, X., 2013. Assessing inundation damage and timing of adaptation: sea level rise and the complexities of land use in coastal communities. Mitigation and Adaptation Strategies for Global Change DOI 10.1007/s11027- 013-9448-0

Marfai, Muh Aris and Lorenz King, 2008. Potential vulnerability implications of coastal inundation due to sea level rise for the coastal zone of Semarang city. Indonesia. Environmental Geology, 54, 1235-1245.

Marfai, Muh Aris and Hizbaron Dyah R., 2011. Community’s adaptive capacity due to coastal flooding in Semarang coastal city, Indonesia. Analele Universitatii din Oradea-Seria Geogrfie, 2, XXI, 209-221.

Mani Murali, R., Shrivastava, D., Vethamony, P., 2009. Monitoring shoreline environment of Paradip, east coast of India using remote sensing. Current Science. 97(1), 79-84.

Mani Murali, R., Unnikrishnan, A.S., Vethamony, P., 2010. Vulnerability of select Indian coastal regions to climate change, Clim ECO2 summer school in IUEM,Brest, http://hal.univ-brest.fr/hal-00502799

Mani Murali, R., Ankita, M., Amrita, S., Vethamony, P., 2013. Coastal vulnerability assessment of Puducherry coast, India, using the analytical hierarchical process. Natural Hazards and Earth System Sciences. 13, 3291-3311. doi:10.5194/nhess-13- 3291-2013

Mani Murali,R., 2014. Application of Geo -spatial Technologies in Coastal Vulnerability Studies Due to Sea Level Rise (SLR) Along the Central Orissa Coast, India. In: J. Sundaresan et al. (eds.), Geospatial Technologies and Climate Change, Geotechnologies and the Environment 10, DOI 10.1007/978-3-31901689-4_11, Springer International Publishing Switzerland２014, pp. 187-199

Nicholls, R.J. and Nobuo Mimura., 1998. Regional issues raised by sea level rise and their policy implications. Climate Research, Vol.11, 5-18.

Nicholls, R.J., Hoozemans, F.M.J., and Marchand, M., 1999. Increasing flood risk and wet land losses due to global sea level rise: Regional and global analyses. Global Environmental Change, 9, pp.S69-S87

NIO report , 2010, Impact and Vulnerability studies along the coast of India to projected sea-level rise and changes in extreme sea level, NIO/SP-22/2010

NOAA Report, 1999. The ocean's role in climate variability and change and the resulting impacts on coasts. NOAA Report, Vol.23, No.2, NOAA, Silver Spring, M.D., USA, 319p

Prasanna Kumar, S., 1985. Studies on sediment transport in the surf zone along ceratin beaches of Kerala. Ph.D Thesis, Cochin University of Science and Technology, Cochin, India, 110p. 
Priju, C.P., Athira1, S.G., Neerajamol, T.P., Madhavan, K., Narasimha Prasad, N.B., 2012. Groundwater quality with special reference to salinity intrusion in Cochin area, Kerala. In: Proceedings of Fifth International Groundwater Conference (IGWC-2012) on the assessment and management of groundwater resources in hard rock systems with special reference to basaltic terrain. C.Mayilswami, M.Thangarajan, P.S.Kulkarni \& VP. Singh (Eds). 152 - 179

Rahmstorf, S., 2012. Sea level rise: Towards understanding local variability. Environmental Research Letters, Vol. 7, No.2, 3-5.

Reece, S.J., Noss, F.R., Oetting, J., Hoctor, T.,Volk, M., 2013. A Vulnerability Assessment of 300 Species in Florida: Threats from Sea Level Rise, Land Use, and Climate Change. PLOS One 8(11), e80658. doi:10.1371/journal.pone.0080658

Robert J.N. Devoy, 2008. Coastal vulnerability and the implicationsof sea level rise for Ireland, Journal of Coastal Research, 24,2, 325-341.

Sajeev, R., 1993. Beach dynamics of Kerala coast in relation to land-sea interaction. Ph.D Thesis, Cochin University of Science and Technology, Cochin, 130p.

Shenoi, S.S.C., 1984. Studies on the littoral processes in relation to stability of beaches around Cochin. Ph.D Thesis, University of Cochin, India, 145 p.

Simav, Ozlem, ZaferSeker Dursunand Gazioglu, 2013. Coastal inundation due to sea level rise and extreme sea state andits potential impacts: Cukurova Delta case. Turkish Journal of Earth Sciences, 22, 1-10.

Solomon, S., Quin, D., Manning, M., Chen, Z., Marquis, M., Averyt, K.B., Tignor, M. and Miller, H.I., 2007. Climate Change 2007: The Physical Science Basis. Contribution of Working group I to the Fourth Assessment Report of the Intergovermental Panel on Climate Change. Cambridge University Press, Cambridge, UK.

Unnikrishnan A S, Kumar K R et al. (2006), Sea level changes along the Indian coast?: Observations and projections, Curr Sci India, 90(3).

Unnikrishnan A S and Shankar D, (2007), Are sea-level-rise trends along the coasts of the north Indian Ocean consistent with global estimates? Global Planet Change, 57:301-307, doi:10.1016/j.gloplacha.2006.11.029.

Xingong Li, Rex J. Rowley, John C. Kostelnick, David Braaten, Joshua Meisel and Kalonie Hulbutta, 2009. GIS analysis of global impacts from sea level rise. Photogrammetric Engineering and Remote Sensing. Vol.75, No.7, 807-818.

Wassmann, R., Hien, H.N., Hoanh, T.C., Tuong, P.T., 2004. Sea level rise affecting the Vietnamese Mekong delta: Water elevation in the flood season and implications for rice production. Climatic Change 66, 89-107 
Table 1. Area and Percentage of LULC classes within 1m elevation

\begin{tabular}{|l|l|l|}
\hline LU/LC class & Area (Sq .km) & \% of area \\
\hline Water & 46.6402 & 27.5797 \\
\hline vegetation & 78.2576 & 46.2760 \\
\hline sandy area & 0.9333 & 0.55188 \\
\hline Urban & 43.0915 & 25.4812 \\
\hline Total & 169.1105 & 100 \\
\hline
\end{tabular}

Table 2. Area and Percentage of LULC classes within $\mathbf{2} \mathrm{m}$ elevation

\begin{tabular}{|l|l|l|}
\hline LU/LC & Area (Sq.km) & \% of area \\
\hline Water & 111.7918 & 18.6684043 \\
\hline vegetation & 292.852 & 48.9041194 \\
\hline sandy area & 5.9366 & 0.99136832 \\
\hline Urban & 187.2828 & 31.2748433 \\
\hline Total & 598.8289 & 100 \\
\hline
\end{tabular}

Table 3. LULC area for the $1 \mathrm{~m}$ and $\mathbf{2} \mathrm{m}$ water level scenarios

\begin{tabular}{|l|l|l|l|}
\hline Sea level rise & Vegetation & Settlements & Sandy area \\
\hline $1 \mathrm{~m}$ & 78.2576 & 43.0915 & 0.9333 \\
\hline $2 \mathrm{~m}$ & 292.852 & 187.2828 & 5.9366 \\
\hline
\end{tabular}




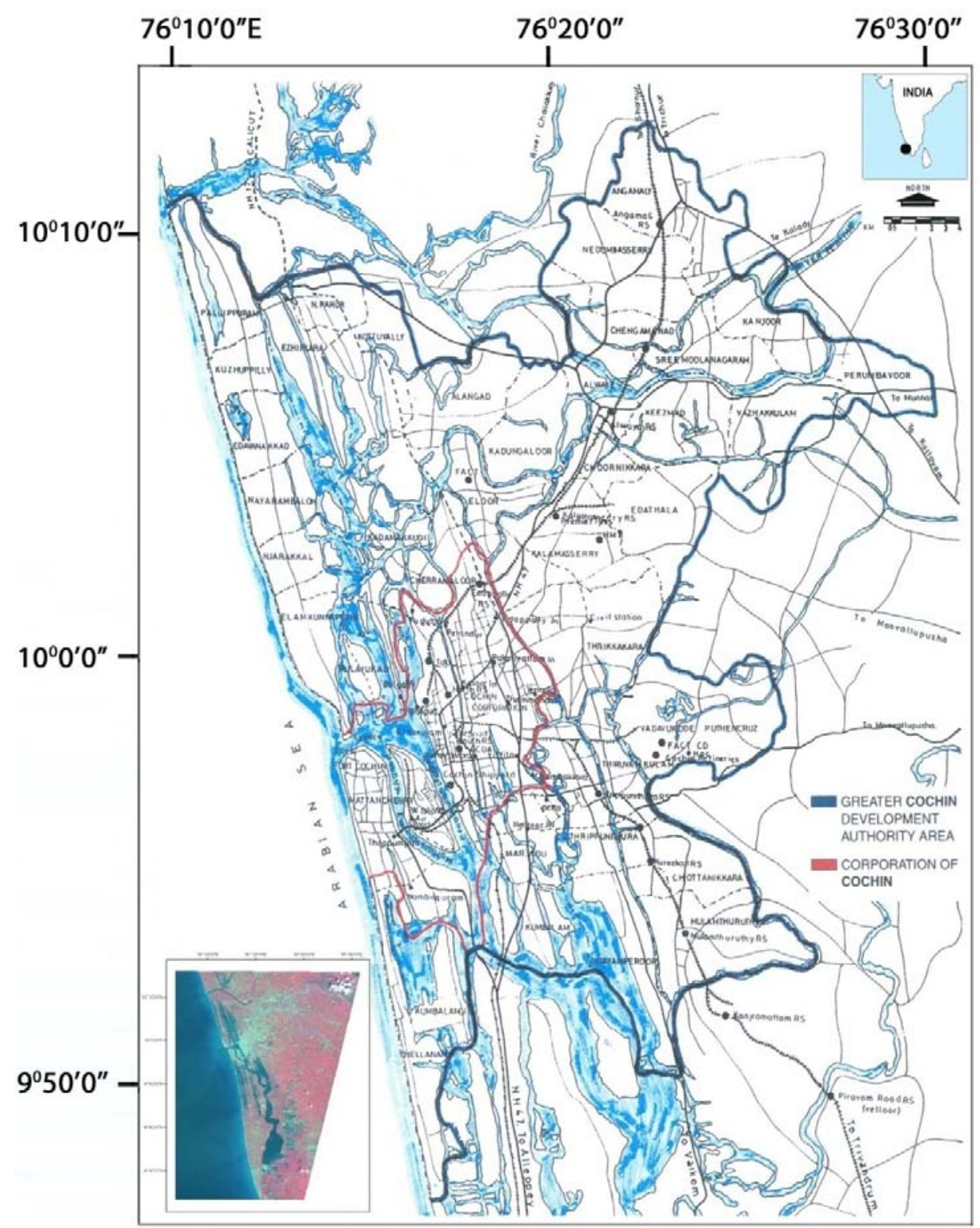

Figure 1. Location map with the IRS P 6 LISS-3 image. 


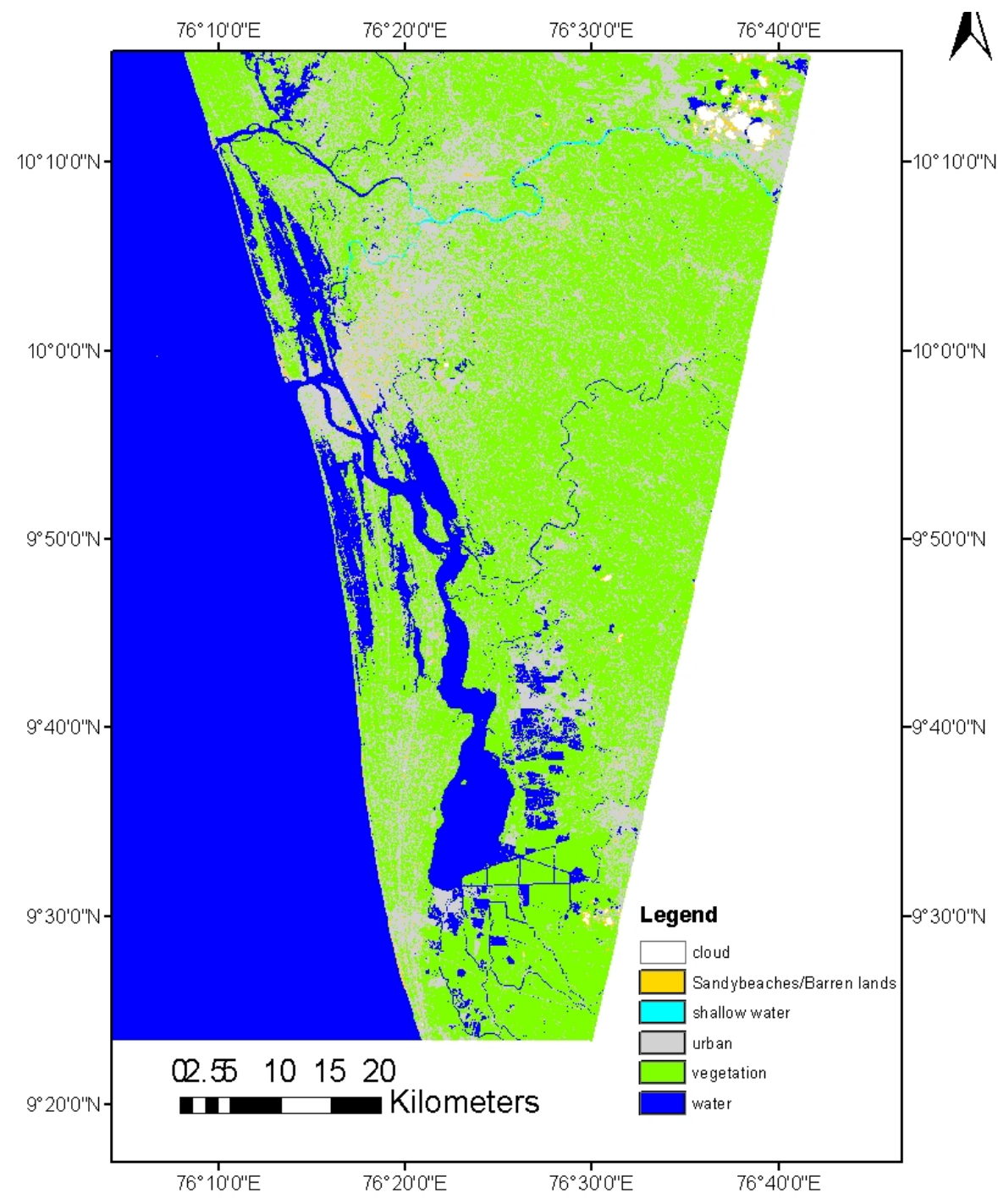

Figure 2. Land use/Land cover of the study area 


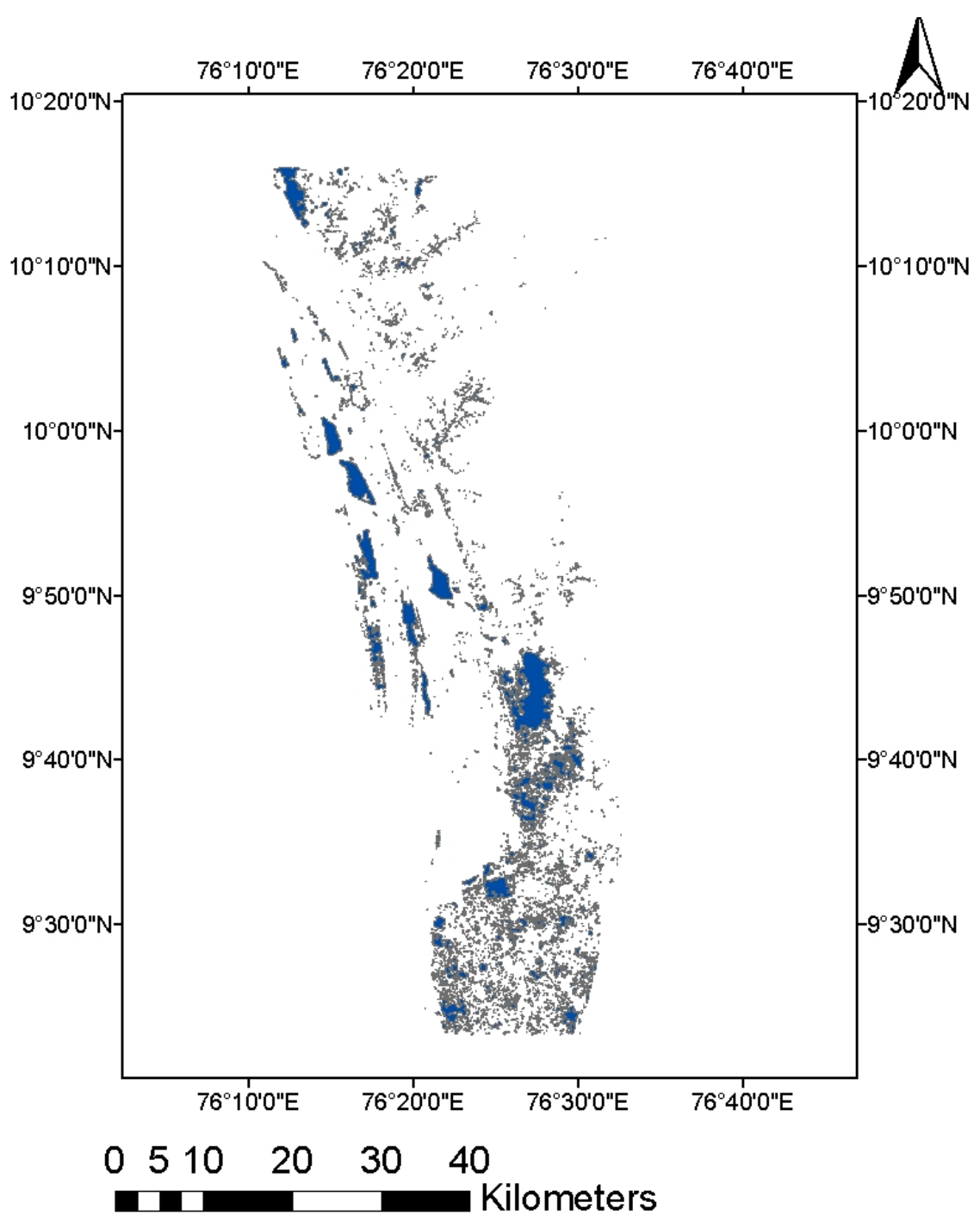

Figure 3. 1 meter elevation map 


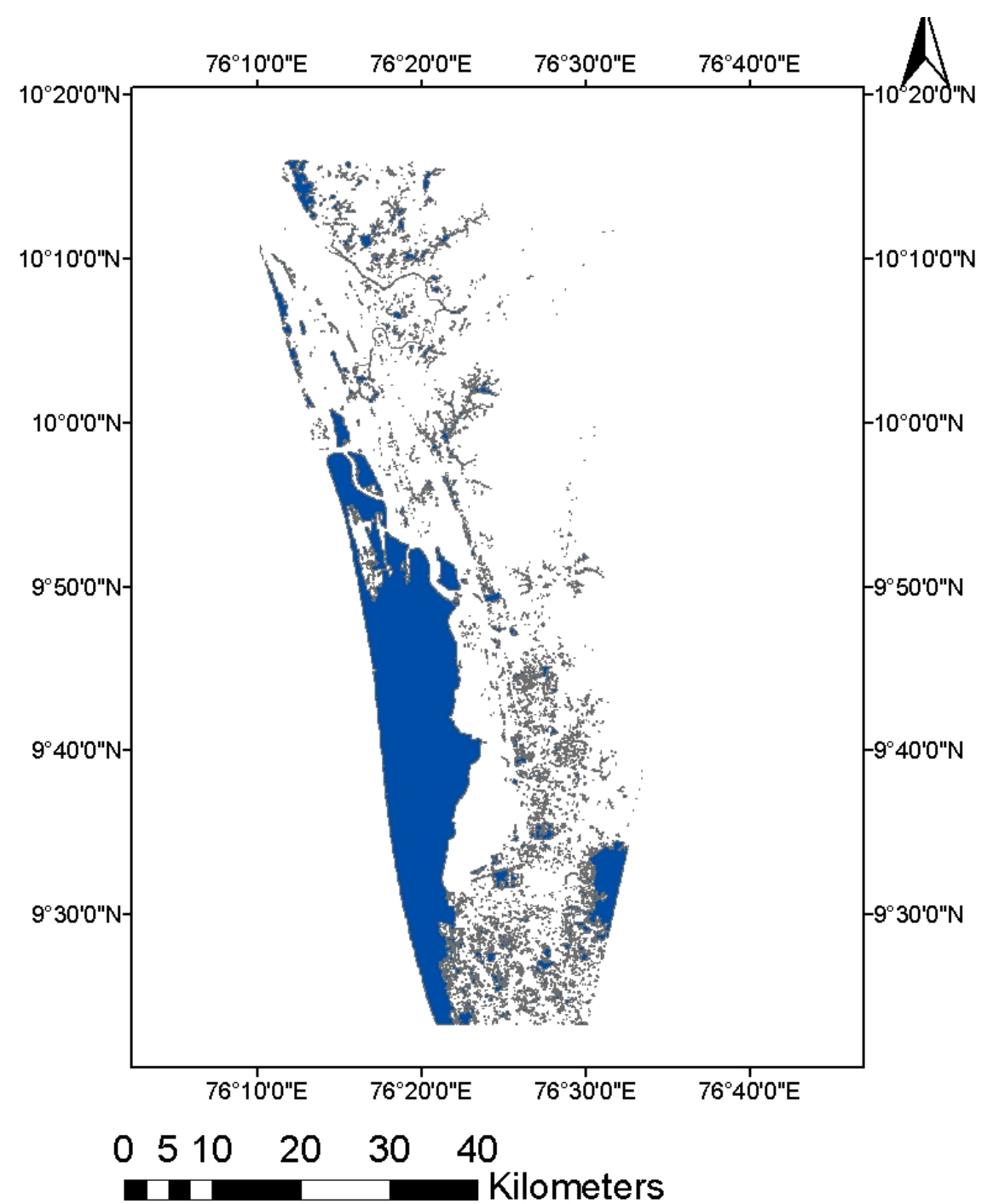

Figure 4. 2 meter elevation map 


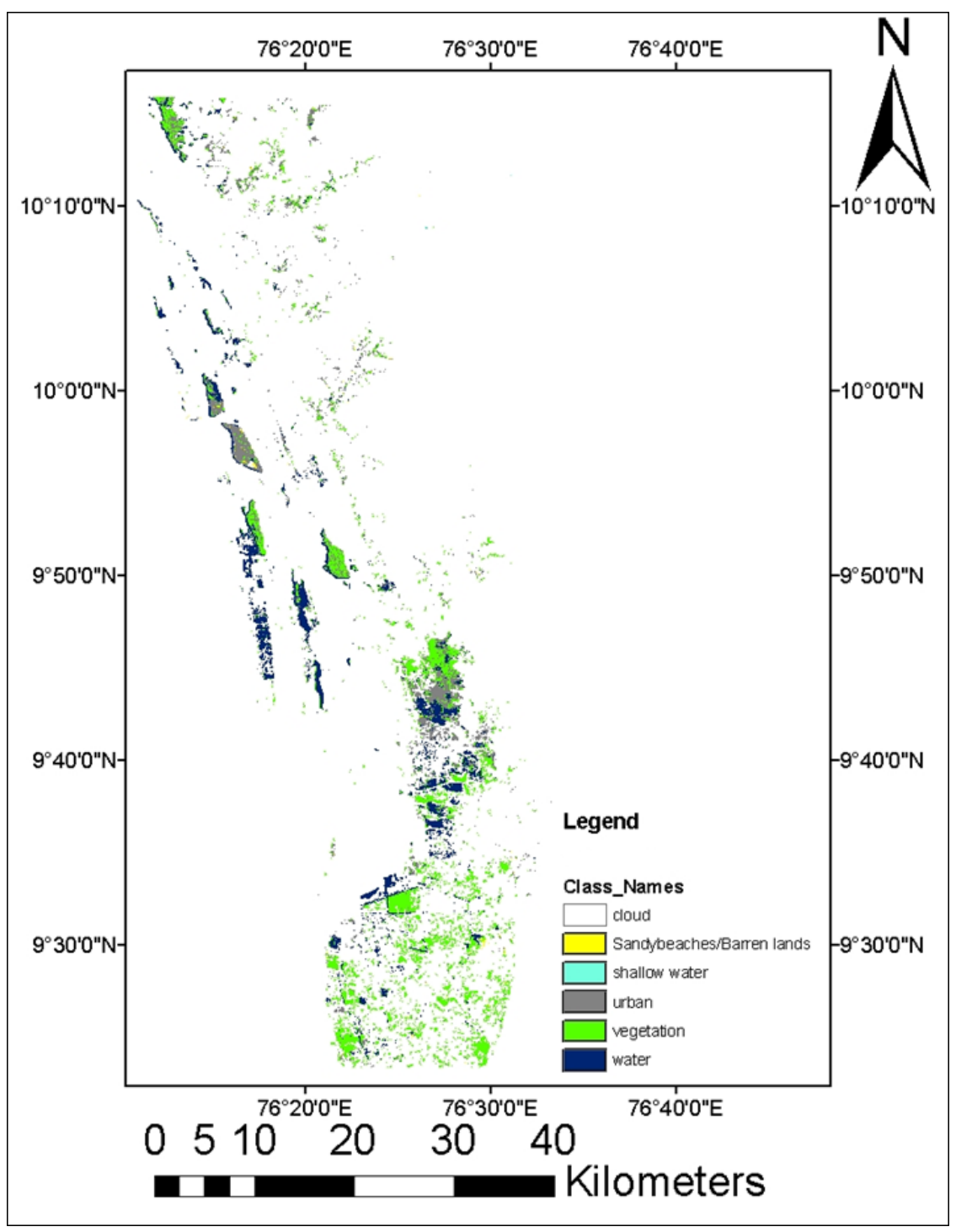

Figure 5. LULC cover on $1 \mathrm{~m}$ elevation. 


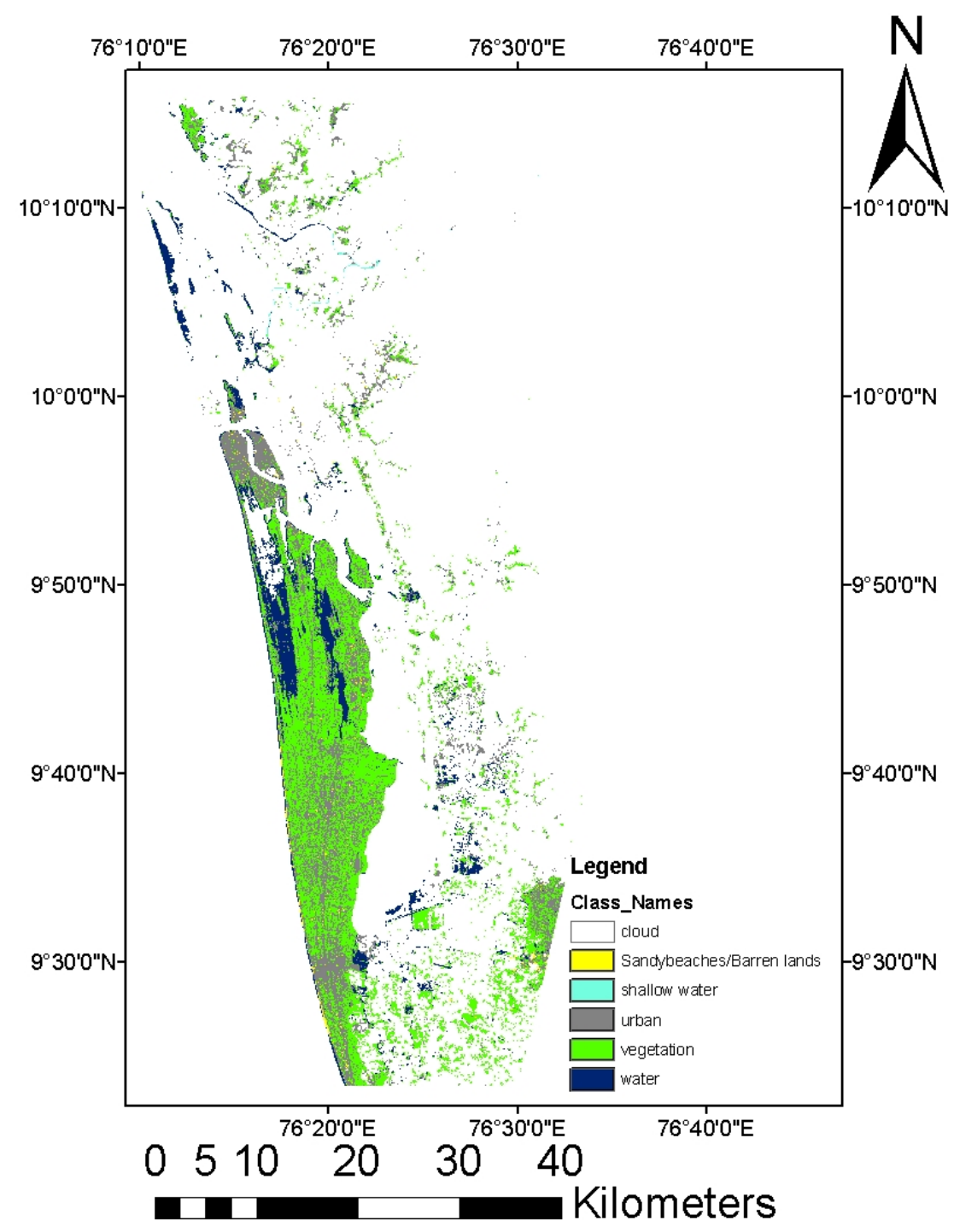

Figure 6. LULC cover on $\mathbf{2} \mathrm{m}$ elevation 


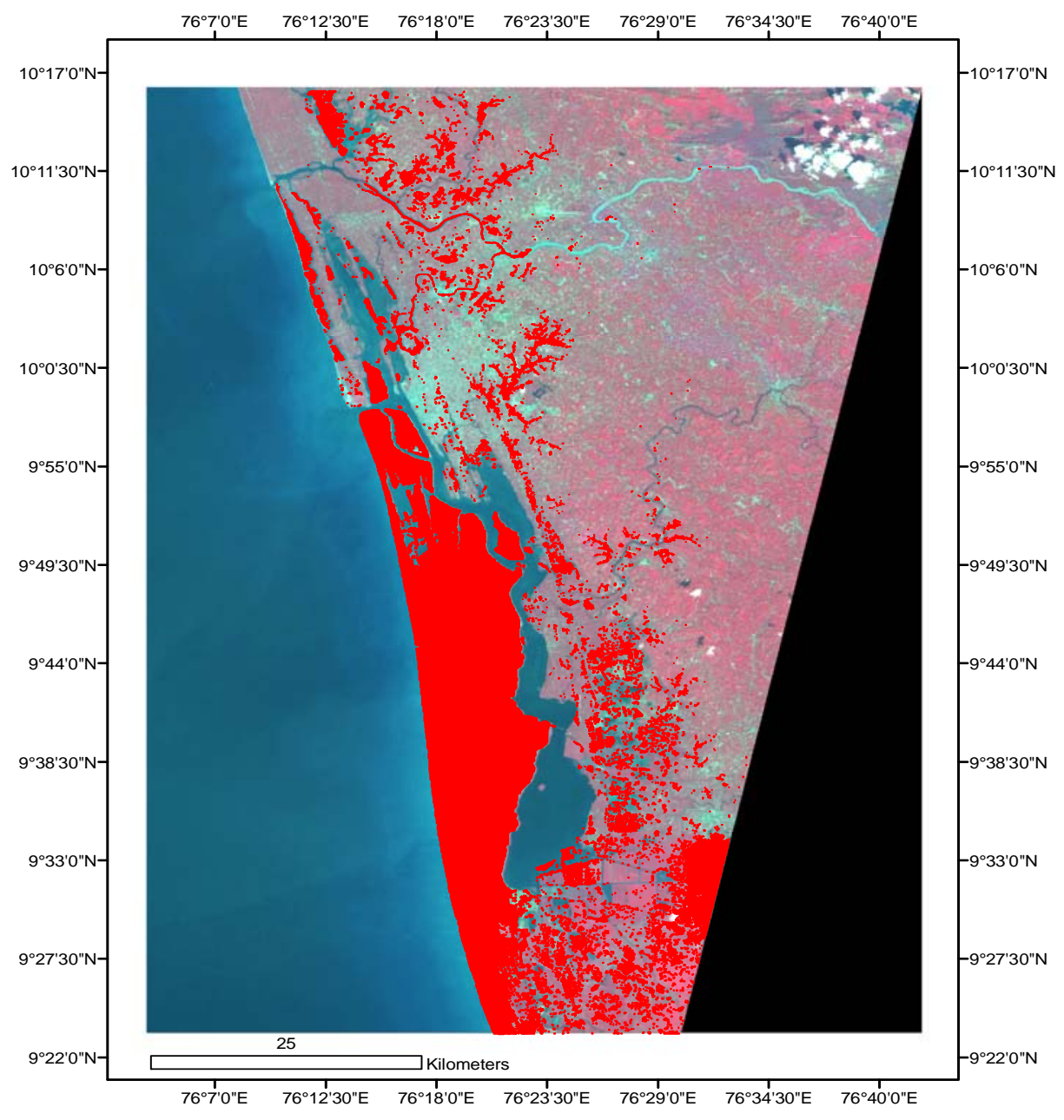

Figure 7. Probable inundation zones for $2 \mathrm{~m}$ sea level rise 